\title{
Biomass production and nutrient content in different Eucalyptus genotypes in Pampa Gaúcho, Brazil
}

\author{
Kristiana Fiorentin dos Santos ${ }^{1} \oplus$, Aline Aparecida Ludvichak ${ }^{1} \oplus$, Tulio Barroso Queiroz ${ }^{2}$, \\ Mauro Valdir Schumacher ${ }^{1}\left[\right.$, Elias Frank de Araújo ${ }^{3}$ ]

\footnotetext{
1 Universidade Regional de Blumenau, Blumenal, SC, Brasil. E-mail: kristianafiorentin@gmail.com; aline_lud@yahoo.com.br; mvschumacher@gmail.com

2 Universidade Estadual Paulista "Júlio de Mesquita Filho", Botucatu, SP, Brasil. E-mail: tulio-bq@hotmail.com

${ }^{3}$ Celulose Riograndense, Guaíba, RS, Brasil. E-mail: elias.araujo@cmpcrs.com.br
}

ABSTRACT: The objective of this study was to estimate the biomass, nutrient stocks, and simulate the export of nutrients, in different genotypes of Eucalyptus. The experiment was conducted in São Gabriel, RS, Brazil, in 43-month-old stands. The selected trees were fractionated into leaves, branches, stembark and stemwood. An estimate of nutrient exports by biomass was calculated for three scenarios. The amount of total biomass ranged from 33.68 to $84.00 \mathrm{Mg} \mathrm{ha}^{-1}$, with the highest production being $E$. uroglobulus, and $E$. dunnii the lowest. The tree canopy accumulated between $47 \%$ and $65 \%$ of the total macronutrients and $46 \%$ to $67 \%$ of the total micronutrients ( $E$. benthamii (P2) and $E$. urograndis). The highest amount of nutrients exported with biomass harvesting, for the first and second scenario (harvesting the stemwood and harvesting the stemwood with stembark), occurred in E. uroglobulus ( $\mathrm{N}, \mathrm{K}$, and $\mathrm{S})$, E. urograndis ( $\mathrm{P}, \mathrm{Mg}$, and $\mathrm{Cu}$ ) and $\mathrm{E}$. saligna (Fe, $\mathrm{Zn}$, and B). For the third scenario (stem and canopy), the highest nutrient exportation occurred in $E$. urograndis, except for $S$, where the highest removal occurred in $E$. uroglobulus. The harvesting of only the stemwood resulted in the removal of the least nutrients from the system, independent of the genotypes.

\section{Produção de biomassa e conteúdo de nutrientes em diferentes genótipos de Eucalyptus no Pampa gaúcho}

RESUMO: O objetivo deste trabalho foi estimar a biomassa, o estoque de nutrientes e simular a exportação de nutrientes em diferentes genótipos de Eucalyptus. 0 experimento foi conduzido em São Gabriel, RS, em povoamentos com 43 meses de idade. As árvores selecionadas foram fracionadas em folhas, galhos, casca do fuste e madeira do fuste. A estimativa da exportação de nutrientes por biomassa foi calculada para três cenários. A quantidade de biomassa total variou de 33,68 a 84,00 $\mathrm{Mg} \mathrm{ha}^{-1}$, destacando-se o E. uroglobulus com a maior produção e o $E$. dunnii com a menor. A copa das árvores acumulou entre $47 \%$ e $65 \%$ do total de macronutrientes e $46 \%$ a $67 \%$ do total de micronutrientes (E. benthamii (P2) e E. urograndis). Para 0 primeiro e segundo cenário (colheita da madeira do fuste e colheita da madeira do fuste com casca), a maior quantidade de nutrientes exportados ocorreu no E. uroglobulus (N, K e S), E. urograndis (P, Mg e Cu) e E. saligna (Fe, Zn e B). Para o terceiro cenário (fuste e copa), a maior exportação de nutrientes ocorreu no $E$. urograndis, com exceção de $S$, onde a maior remoção ocorreu no $E$. uroglobulus. A colheita apenas da madeira do fuste apresentou a menor remoção de nutrientes do sistema, independente do genótipo.

Palavras-chave: clones de Eucalyptus; nutrição de florestas; silvicultura; sustentabilidade 


\section{Introduction}

In recent years, the Brazilian planted forest sector has gained great importance worldwide. With a planting area of 9.8 million hectares, the genus Eucalyptus occupy $75.2 \%$ of the planted area (IBGE, 2017). The wide range of Eucalyptus species adapted to different soil and climatic conditions and the possibility of using eucalypts wood for a variety of purposes has stimulated the establishment of plantations by large and small enterprises (Gonçalves et al., 2013). One of the main benefits of eucalypts stands is that it offers an alternative supply of wood, thereby reducing the pressure on native forests. This is important because even if the native forests could be used sustainably, they would not be sufficient to meet the growing demand of wood (Viera et al., 2012).

Forestry biomass is an important information in maintaining the balance of biogeochemical cycles and its measurement provides an efficient means of evaluating energy conversion and nutrient cycling within the stand (Viera et al., 2015). This variable is determined by the amount of solar radiation intercepted by the canopy and by the conversion efficiency of the biomass radiation (Santana et al., 2008).

The distribution of nutrients in the components of the trees has great importance in the nutrition of forest stands managed in successive rotations, because of the intensive management of eucalypts plantations can not only increase biomass production, but it also can augment nutrient removal (Viera et al., 2013). Therefore, knowledge of the distribution of biomass and nutrients in the different components of the tree can support numerous practices aimed at maintaining productivity, such as: definition of age and harvest intensity, management of forest residues, replacement fertilization, and soil preparation, among others (Schumacher et al., 2013).

The continued success of future plantations will depend on the ability of forest managers to achieve high production levels of wood sustainable (Gonçalves et al., 2013). That is, utilizing site management techniques that keep crop residues at the on the soil surface for maximum efficiency of nutrient cycling (Santana et al., 2002). Therefore, knowledge of the nutrient export rate by different genotypes is essential for the adoption of nutrient conservation and replenishment techniques to the ecosystem (Santana et al. 1999).

Thus, studies on the production of biomass and nutrient stocks of different species/provenances planted in the same soil and climatic conditions is essential for the selection of genotypes needed for achieving higher productivity in a sustainable way. This study aims to estimate the biomass and the nutrient stocks, and to simulate the export of nutrients in different genotypes of Eucalyptus.

\section{Materials and Methods}

\section{Characterization of the site}

The experiment was conducted in the Region of the Campanha in São Gabriel, Rio Grande do Sul, Brazil, in the Horto Florestal Batovi, owned by Celulose Riograndense -
CMPC $\left(30^{\circ} 26^{\prime} 51.68^{\prime \prime} \mathrm{S}\right.$ and $\left.54^{\circ} 32^{\prime} 25.89^{\prime \prime} \mathrm{W}\right)$. The site is more than $300 \mathrm{~km}$ from the South Atlantic Ocean at an approximate altitude of $154 \mathrm{~m}$.

The climate of the region is characterized as subtropical humid ( $\mathrm{Cfa}$ ), according to the climatic classification of Köppen. The average annual temperature is approximately $18.1^{\circ} \mathrm{C}$, with $24.2{ }^{\circ} \mathrm{C}$ being the mean maximum temperature and $12,6^{\circ} \mathrm{C}$ the mean minimum temperature. The average annual precipitation reaches $1,854 \mathrm{~mm}$ (Alvares et al., 2013).

The soil in the experimental area is of the typical Luvisol Haptic Otic type. Luvisols comprise non-hydromorphic mineral soils, ranging from well to imperfectly drained, usually shallow, with horizons A, Bt and C (Embrapa, 2009). Table 1 presents the physical and chemical attributes of the soil at depths from 0 to $100 \mathrm{~cm}$.

Planting was happened out in November 2012, with a spacing of $3.50 \mathrm{~m} \times 2.14 \mathrm{~m}$, with density of 1,335 trees per ha. Settling of the ground, liming with $2 \mathrm{Mg} \mathrm{ha}^{-1}$ of limestone, subsoiling down to $50 \mathrm{~cm}$, and setting up of ridges $(40 \mathrm{~cm}$ high). During planting, $200 \mathrm{~kg} \mathrm{ha}^{-1}$ of single superphosphate was applied to the groove at a rate of $100 \mathrm{~g} \mathrm{plant}^{-1}$ in the form of $\mathrm{N}-\mathrm{P}_{2} \mathrm{O}_{5}-\mathrm{K}_{2} \mathrm{O}$ (06:30:06) $+\mathrm{Zn}$ on the occasion of planting.

Subsequently, two post-planting fertilizations were performed at six and twelve months in the form of $150 \mathrm{~kg}$ $\mathrm{ha}^{-1}$ of $\mathrm{N}-\mathrm{P}_{2} \mathrm{O}_{5}-\mathrm{K}_{2} \mathrm{O}(12: 00: 20)+0.5 \% \mathrm{~B}$ and $150 \mathrm{~kg} \mathrm{ha}^{-1}$ of $\mathrm{N}-\mathrm{P}_{2} \mathrm{O}_{5}-\mathrm{K} 2 \mathrm{O}$ (24:00:26), respectively. In addition, the following cultural practices were performed: prior to planting, chemical weeding was performed in total area with $2.5 \mathrm{~kg} \mathrm{ha}^{-1}$ Scout (glyphosate). At 10 days after planting, $3.5 \mathrm{~L} \mathrm{ha}^{-1}$ of the preemergent Oxyfluofen was applied. At four and nine months after planting, weed and chemical weeding were performed using $1.7 \mathrm{~kg} \mathrm{ha}^{-1}$ of Scout (glyphosate).

The following Eucalyptus clones were planted: $E$. benthamii (P1), E. benthamii (P2), E. saligna, E. dunnii, hybrid of $E$. urophylla $\times E$. globulus (E. uroglobulus), and hybrid of $E$. urophylla $\times E$. grandis (E. urograndis). E. benthamii (P1) is a provenance originating from Guarapuava, Paraná, Brazil and E. benthamii (P2) is from Telêmaco Borba, Paraná, Brazil. At the time of data collection, the stands were 43 months old.

For each genotype, a plot of 8 lines per 10 plants was demarcated, where the DBH (diameter at breast height, measured at $1.30 \mathrm{~m}$ above ground level) of all individuals was measured with diametrical tape. The heights of $20 \%$ of the plants were measured using a Vertex hypsometer; thus, the heights that were not measured in the field were estimated through hypsometric models. Table 2 presents the dendrometric variables obtained in the different genotypes of Eucalyptus, at 43 months of age established in São Gabriel, RS, Brazil.

\section{Biomass and nutrient stocks}

Based on the data obtained in the plot inventory, three trees mean were sampled for each genotypes. The selected trees were felled and separated in the following components: leaves, branches, stembark and stemwood. Sampling of the wood and bark of the stem was done by dividing the trunk into three sections of equal parts, with the sampling performed on three points in the median position of each section. 
Table 1. Physical and chemical attributes of the soil of the area implanted with different genotypes of Eucalyptus at 43-monthold age in São Gabriel, RS, Brazil.

\begin{tabular}{|c|c|c|c|c|c|c|c|c|c|c|c|c|c|c|c|c|}
\hline \multirow{2}{*}{ Genotypes } & \multirow{2}{*}{$\begin{array}{l}\text { Depth } \\
\text { (cm) }\end{array}$} & \multirow{2}{*}{$\mathrm{pH}$} & \multirow{2}{*}{$\begin{array}{c}\mathrm{Sd} \\
\left(\mathrm{g} \mathrm{cm}^{-3}\right)\end{array}$} & Clay & $O . M$ & $M$ & $\mathbf{t}$ & Al & $\mathrm{Ca}$ & $\mathrm{Mg}$ & $\mathbf{P}$ & $\mathbf{K}$ & $\mathrm{s}$ & B & $\mathrm{Cu}$ & $\mathrm{Zn}$ \\
\hline & & & & & $(\%)$ & & \multicolumn{4}{|c|}{$\left(\mathrm{cmol}_{\mathrm{c}} \mathrm{dm}^{-3}\right)$} & \multicolumn{6}{|c|}{$\left(\mathrm{mg} \mathrm{dm}^{-3}\right)$} \\
\hline \multirow{6}{*}{ E. benthamii $(\mathrm{P} 1)$} & $0-10$ & 4.7 & 1.30 & 15 & 3.4 & 13.7 & 7.3 & 1.0 & 3.9 & 2.3 & 2.3 & 53.0 & 8.1 & 0.5 & 2.1 & 1.7 \\
\hline & $10-20$ & 5.1 & 1.31 & 19 & 2.8 & 27.1 & 6.7 & 1.8 & 3.3 & 1.5 & 1.3 & 31.0 & 5.9 & 0.6 & 2.2 & 0.8 \\
\hline & $20-40$ & 5.3 & 1.35 & 21 & 2.1 & 33.3 & 6.6 & 2.2 & 3.1 & 1.2 & 0.8 & 27.0 & 2.5 & 0.3 & 1.5 & 0.4 \\
\hline & $40-60$ & 5.4 & 1.19 & 47 & 2.1 & 14.6 & 19.2 & 2.8 & 11.6 & 4.7 & 0.6 & 70.0 & 2.4 & 0.5 & 1.9 & 0.5 \\
\hline & $60-80$ & 5.5 & 1.47 & 33 & 0.9 & 0.0 & 26.0 & 0.0 & 18.0 & 7.7 & 0.4 & 92.0 & 20.0 & 0.4 & 2.1 & 1.1 \\
\hline & $80-100$ & 6.0 & 1.65 & 33 & 0.7 & 0.0 & 27.8 & 0.0 & 19.4 & 8.1 & 0.6 & 96.0 & 29.0 & 0.5 & 0.9 & 0.5 \\
\hline \multirow{6}{*}{ E. benthamii (P2) } & $0-10$ & 4.9 & 1.23 & 23 & 2.8 & 33.4 & 6.6 & 2.2 & 3.4 & 1.0 & 1.2 & 33.0 & 4.1 & 0.3 & 2.5 & 0.7 \\
\hline & $10-20$ & 5.1 & 1.34 & 25 & 2.2 & 48.9 & 7.6 & 3.7 & 3.3 & 0.5 & 0.7 & 29.0 & 3.4 & 0.3 & 2.1 & 0.5 \\
\hline & $20-40$ & 5.3 & 1.44 & 29 & 1.3 & 49.8 & 6.6 & 3.3 & 2.6 & 0.7 & 0.5 & 26.0 & 2.5 & 0.2 & 1.4 & 0.4 \\
\hline & $40-60$ & 5.2 & 1.55 & 41 & 1.3 & 40.7 & 10.6 & 4.3 & 4.6 & 1.6 & 0.5 & 45.0 & 2.9 & 0.3 & 1.6 & 0.6 \\
\hline & $60-80$ & 5.3 & 1.51 & 41 & 1.0 & 28.9 & 12.8 & 3.7 & 6.5 & 2.5 & 0.2 & 52.0 & 5.8 & 0.3 & 1.1 & 0.4 \\
\hline & $80-100$ & 5.3 & 1.52 & 47 & 1.0 & 21.0 & 15.7 & 3.3 & 8.5 & 3.8 & 0.2 & 63.0 & 4.9 & 0.3 & 1.7 & 0.5 \\
\hline \multirow{6}{*}{ E. saligna } & $0-10$ & 5.1 & 1.20 & 17 & 3.0 & 30.5 & 6.5 & 2.0 & 2.7 & 1.8 & 1.4 & 35.0 & 13.0 & 0.3 & 2.4 & 1.0 \\
\hline & $10-20$ & 5.1 & 1.25 & 19 & 2.7 & 35.3 & 7.4 & 2.6 & 3.3 & 1.4 & 1.0 & 30.0 & 12.0 & 0.2 & 2.4 & 0.8 \\
\hline & $20-40$ & 5.2 & 1.37 & 25 & 1.9 & 61.5 & 6.0 & 3.7 & 1.8 & 0.5 & 0.5 & 21.0 & 9.7 & 0.2 & 2.0 & 0.6 \\
\hline & $40-60$ & 5.3 & 1.32 & 37 & 1.4 & 60.5 & 10.4 & 6.3 & 3.1 & 0.9 & 0.4 & 33.0 & 13.0 & 0.3 & 2.2 & 0.6 \\
\hline & $60-80$ & 5.3 & 1.31 & 43 & 1.3 & 26.4 & 14.8 & 3.9 & 7.5 & 3.3 & 0.4 & 65.0 & 12.0 & 0.3 & 2.6 & 0.7 \\
\hline & $80-100$ & 5.3 & 1.53 & 19 & 1.0 & 9.7 & 18.7 & 1.8 & 12.3 & 4.4 & 0.2 & 73.0 & 15.0 & 0.3 & 2.6 & 1.0 \\
\hline \multirow{6}{*}{ E. dunnii } & $0-10$ & 5.1 & 1.34 & 13 & 2.7 & 30.4 & 6.6 & 2.0 & 2.8 & 1.7 & 1.1 & 33.0 & 9.2 & 0.3 & 2.2 & 0.9 \\
\hline & $10-20$ & 5.3 & 1.36 & 21 & 1.9 & 37.1 & 6.5 & 2.4 & 2.8 & 1.2 & 0.5 & 28.0 & 6.8 & 0.3 & 1.5 & 0.9 \\
\hline & $20-40$ & 5.3 & 1.38 & 29 & 1.5 & 26.8 & 10.4 & 2.8 & 5.3 & 2.3 & 0.5 & 44.0 & 8.3 & 0.3 & 1.4 & 0.5 \\
\hline & $40-60$ & 5.2 & 1.08 & 47 & 2.2 & 30.6 & 22.5 & 6.9 & 11.4 & 4.0 & 0.3 & 79.0 & 12.0 & 0.3 & 2.1 & 0.6 \\
\hline & $60-80$ & 5.1 & 1.34 & 55 & 1.5 & 7.7 & 28.5 & 2.2 & 18.8 & 7.1 & 0.2 & 108.0 & 12.0 & 0.3 & 2.7 & 0.9 \\
\hline & $80-100$ & 5.3 & 1.49 & 41 & 0.8 & 2.2 & 27.9 & 0.6 & 19.7 & 7.2 & 0.2 & 124.0 & 11.0 & 0.5 & 1.8 & 0.6 \\
\hline \multirow{6}{*}{ E. uroglobulus } & $0-10$ & 5.0 & 1.26 & 21 & 2.8 & 31.4 & 7.0 & 2.2 & 3.2 & 1.5 & 1.3 & 30.0 & 5.7 & 0.3 & 2.2 & 0.8 \\
\hline & $10-20$ & 5.1 & 1.26 & 25 & 2.4 & 41.6 & 7.9 & 3.3 & 3.4 & 1.2 & 0.6 & 34.0 & 4.4 & 0.2 & 1.6 & 0.4 \\
\hline & $20-40$ & 5.2 & 1.34 & 27 & 1.7 & 56.3 & 8.4 & 4.7 & 2.7 & 0.9 & 0.4 & 32.0 & 5.0 & 0.2 & 1.3 & 0.4 \\
\hline & $40-60$ & 5.4 & 1.34 & 31 & 1.4 & 43.9 & 10.7 & 4.7 & 4.5 & 1.4 & 0.3 & 49.0 & 1.9 & 0.3 & 1.6 & 0.6 \\
\hline & $60-80$ & 5.4 & 1.22 & 49 & 1.7 & 24.2 & 21.9 & 5.3 & 12.0 & 4.4 & 0.2 & 87.0 & 2.5 & 0.4 & 2.2 & 0.8 \\
\hline & $80-100$ & 5.4 & 1.38 & 53 & 1.1 & 6.1 & 26.4 & 1.6 & 17.4 & 7.1 & 0.2 & 131.0 & 3.2 & 0.3 & 2.3 & 0.7 \\
\hline \multirow{6}{*}{ E. urograndis } & $0-10$ & 5.2 & 1.33 & 17 & 2.7 & 27.3 & 8.1 & 2.2 & 3.8 & 2.0 & 1.4 & 46.0 & 16.0 & 0.2 & 2.8 & 1.1 \\
\hline & $10-20$ & 5.3 & 1.39 & 23 & 2.5 & 36.5 & 8.2 & 3.0 & 3.7 & 1.5 & 1.4 & 32.0 & 9.2 & 0.1 & 2.8 & 1.2 \\
\hline & $20-40$ & 5.3 & 1.39 & 27 & 1.9 & 47.9 & 8.6 & 4.1 & 3.4 & 1.0 & 0.6 & 34.0 & 9.5 & 0.1 & 2.1 & 0.8 \\
\hline & $40-60$ & 5.5 & 1.52 & 13 & 1.5 & 1.9 & 21.6 & 0.4 & 15.6 & 5.4 & 0.5 & 83.0 & 14.0 & 0.2 & 3.1 & 0.9 \\
\hline & $60-80$ & 5.9 & 1.71 & 45 & 0.9 & 0.0 & 21.4 & 0.0 & 15.8 & 5.4 & 0.5 & 95.0 & 13.0 & 0.3 & 1.3 & 0.6 \\
\hline & $80-100$ & 6.3 & 1.73 & 41 & 0.4 & 0.0 & 27.8 & 0.0 & 20.2 & 7.3 & 0.5 & 103.0 & 10.0 & 0.2 & 1.0 & 0.7 \\
\hline
\end{tabular}

Sd: soil density; O.M: organic matter, digestion by wet combustion $\left(\mathrm{K}_{2} \mathrm{Cr}_{2} \mathrm{O}_{7}+\mathrm{H}_{2} \mathrm{SO}_{4}\right)$; $\mathrm{pH}$ in $\mathrm{H}_{2} \mathrm{O}(1: 1) ; \mathrm{Al}$, $\mathrm{Ca}$ e $\mathrm{Mg}$ exchangeable, solution extraction $\mathrm{KCl}\left(1\right.$ mol $\left.\mathrm{L}^{-1}\right)$; $\mathrm{P}$ available and $\mathrm{K}$ exchangeable, extracted with Mehlich ${ }^{-1} ; \mathrm{t}$ : Effective cation exchange capacity; $\mathrm{m}^{2}=$ Saturation by aluminum. $\mathrm{S}$, by solution of Ca $\left(\mathrm{H}_{2} \mathrm{PO}_{4}\right)_{2}$ the $500 \mathrm{mg}$ of $\mathrm{P} \mathrm{L^{-1 }}$.

Table 2. Dendrometric characterization of different genotypes of Eucalyptus at 43-month-old in São Gabriel, RS, Brazil.

\begin{tabular}{cccc}
\hline Genotypes & $\mathbf{N}^{\circ}$ of individuals per ha & Bolume $\left(\mathrm{m}^{\mathbf{3}}\right.$ ha \\
\hline E. benthamii (P1) & $1168 \pm 174$ & $17.5 \mathrm{bc} \pm 4.4$ & $48.18 \mathrm{c} \pm 19.8$ \\
E. benthamii (P2) & $768 \pm 190$ & $12.1 \mathrm{~d} \pm 4.5$ & $36.01 \mathrm{~d} \pm 15.7$ \\
E. saligna & $1268 \pm 281$ & $19.3 \mathrm{ab} \pm 3.3$ & $57.85 \mathrm{bc} \pm 18.5$ \\
E. dunnii & $1135 \pm 227$ & $10.9 \mathrm{~d} \pm 3.2$ & $26.83 \mathrm{~d} \pm 9.4$ \\
E. uroglobulus & $1285 \pm 395$ & $16.3 \mathrm{c} \pm 3.4$ & $69.56 \mathrm{a} \pm 36.1$ \\
E. urograndis & $1302 \pm 326$ & $20.4 \mathrm{a} \pm 3.6$ & $66.54 \mathrm{ab} \pm 22.2$ \\
\hline
\end{tabular}

Mean of each variable in different treatments (genotypes) followed by equal letters, do not differ significantly by the Tukey test at the $5 \%$ level of error and, values preceded by \pm are the standard deviation of the mean.

All biomass samples were weighed in the field with a precision scale and packed in paper bags. Subsequently they were sent to the laboratory and dried in an oven at $70{ }^{\circ} \mathrm{C}$ with circulation and air exchange until weight stabilization, to determine the moisture content. Based on the dry biomass of each component and the number of trees per hectare of each genotypes, the total biomass per hectare was estimated.
For the determination of nutrients, the samples were ground in a Wiley mill with a 30-mesh screen and subsequently subjected to chemical analysis to determine macronutrient $(\mathrm{N}, \mathrm{P}, \mathrm{K}, \mathrm{Ca}, \mathrm{Mg}$, and $\mathrm{S}$ ) and micronutrients $\mathrm{B}, \mathrm{Cu}, \mathrm{Fe}, \mathrm{Mn}$, and $\mathrm{Zn}$ ), concentrations according to the methodology of Tedesco et al. (1995) and Miyazawa et al. (1999).

The estimates of the nutrient stock for each component was obtained by multiplying the dried biomass by the 
concentration of nutrients. The estimate per hectare was performed by extrapolating the stock per individual based on the number of individuals present in each sampling unit.

\section{Estimation of nutrient removal by harvest}

Estimation of nutrient removal through biomass harvesting was performed for three scenarios based on the nutrient stock of each biomass component:

1) Harvesting the stemwood;

2) Harvesting the stemwood with stembark;

3) Harvesting of all aboveground biomass.

\section{Statistical procedures}

Statistical analyses were performed at a $5 \%$ error probability level with the aid of the statistical software Assistat 7.7 (Silva \& Azevedo, 2009). The biomass and nutrient concentration data were subjected to analysis of variance and Tukey's test for comparison of means between treatments (genotypes).

\section{Results and Discussion}

\section{Aboveground biomass}

The hybrids $E$. uroglobulus and $E$. urograndis produced the highest total biomass ( 84.00 and $80.79 \mathrm{Mg} \mathrm{ha}^{-1}$, respectively), which corresponded to 55.36 and $44.33 \mathrm{Mg} \mathrm{ha}^{-1}$ of stemwood biomass, respectively (Figure 1). The clone E. dunnii produced the lowest total biomass (33.68 $\mathrm{Mg} \mathrm{ha}^{-1}$ ), providing the lowest biomass for all components, except for the branches, where the lowest value was found in E. benthamii (P2). Similar results were also found by Schumacher \& Caldeira (2008) who evaluated a four-year-old E. saligna in the Central Region of RS, Brazil; and by Turner \& Lambert (2008), in a study on fiveyear-old E. grandis in northern New South Wales, Australia. In terms of biomass production of stemwood, the $E$. uroglobulus hybrid produced $39 \%, 40 \%$ and $66 \%$ more than the clones $E$. benthamii (P2), E. benthamii (P1), and E. dunnii, respectively. According to Bellote \& Silva (2005), the main factors that

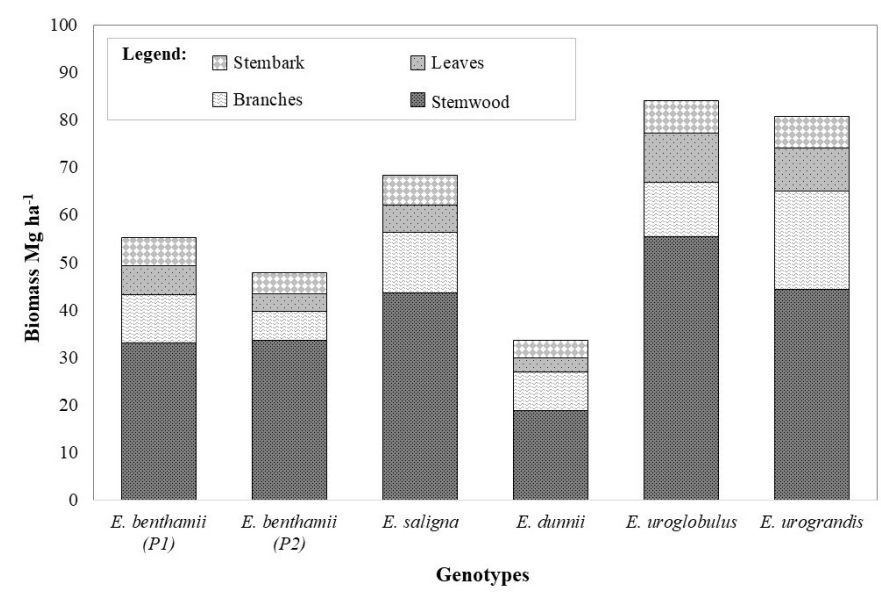

Figure 1. Production and partition of biomass for the different components of Eucalyptus genotypes at 43-month-old established in São Gabriel, RS, Brazil. interfere with forest productivity are related to the genotypes and the soil conditions used.

When treating the components separately, the percentage distribution of aboveground biomass for clones $E$. benthamii (P1), E. uroglobulus and E. urograndis followed the following sequence: stemwood > branches > leaves > stembark. The same order of distribution was found in four-year-old Eucalyptus spp. in Vera Cruz, RS, Brazil (Schumacher et al., 2011); in 18-month-old E. urograndis in Piratini, RS, Brazil (Viera et al., 2012); in the biomass in a clone of $E$. urophylla $\times$ E. grandis, at 5.5 years of age, in the southeastern region of Brazil (Ribeiro et al., 2015); and in the biomass of Eucalyptus spp. in Kenya (Kuyah et al., 2013).

The clones E. dunnii, E. benthamii (P2) and E. saligna presented the following order of distribution and relative partitioning: stemwood > branches > stembark > leaves. Comparing the same components, the relative biomass distribution was the same as that found by Guimarães et al. (2015) in a four-year-old stand of E. dunnii in the city of Alegrete, RS, Brazil. According to Schumacher et al. (2011), the factors that affect the percentage distribution of the biomass in the different components of the trees are species, age, soil fertility and planting density. Therefore, since the genotypes were of the same age, and were planted at the same planting density in the same soil type, the species was the predominant factor that affected biomass distribution.

We verified that the stem (wood and bark) represented $63 \%-79 \%$ of the total biomass produced, with the lowest value in clone $E$. urograndis and the highest in $E$. benthamii (P2). Meanwhile, the canopy (leaves and branches) accounted for $21 \%-37 \%$ of the total biomass. In contrast, Schumacher \& Caldeira (2008), evaluating a four-year-old stand of E. saligna, reported that $82 \%$ of the aerial biomass was distributed in the wood.

Zewdie et al. (2009) studied E. globulus stands with ages between one and nine years and observed that at year one, the leaves and the branches were the components of the trees that presented with the greatest accumulation of biomass. However, at four, five, seven, and nine years, the leaves and branches were responsible for a decreasing percentage of biomass above the soil. Viera et al. (2012), evaluating a hybrid stand of $E$. urograndis at 18 months of age, found that the wood and bark components contributed to approximately $45 \%$ of the total biomass.

\section{Nutrients in biomass}

The different genotypes, belonging to the same genus or even the same species but with different origins, showed variations in nutrient concentrations (Tables 3 and 4). In general terms, the highest concentrations occurred in the leaves and the lowest in the wood of the stem.

We found that $\mathrm{N}, \mathrm{P}$, and $\mathrm{S}$ of the macronutrients concentrated more in the leaves, while $\mathrm{Ca}$ and $\mathrm{Mg}$ accumulated more in the stembark (Table 3), except in $E$. dunnii, where the highest concentration of these elements occurred in the leaves, and in E. urograndis, where $\mathrm{Ca}$ also 
Table 3. Macroutrient concentration in the different biomass components of different genotypes of Eucalyptus at 43-month-old established in São Gabriel, RS, Brazil.

\begin{tabular}{|c|c|c|c|c|c|c|c|}
\hline \multirow{2}{*}{ Genotype } & \multirow{2}{*}{ Fractions } & $\mathbf{N}$ & $\mathbf{P}$ & $\mathbf{K}$ & $\mathrm{Ca}$ & $\mathrm{Mg}$ & $S$ \\
\hline & & \multicolumn{6}{|c|}{$\left(\mathrm{g} \mathrm{kg}^{-1}\right)$} \\
\hline \multirow{4}{*}{ E. benthamii (P1) } & Leaves & $18.11 \mathrm{ab}$ & $1.05 a b$ & $5.96 a b$ & $11.33 a b$ & $2.77 a$ & $1.56 a$ \\
\hline & Branches & $1.98 b$ & $0.14 a$ & $1.90 \mathrm{~b}$ & $10.14 a$ & $1.71 \mathrm{ab}$ & $0.29 a$ \\
\hline & Stembark & $4.03 a$ & $0.41 a b$ & $4.16 \mathrm{bc}$ & 14.16a & $3.12 \mathrm{a}$ & $0.43 a$ \\
\hline & Stemwood & $1.58 a$ & $0.15 a$ & $1.94 a$ & 1.17ab & $0.49 b c$ & $0.20 a$ \\
\hline \multirow{4}{*}{ E. benthamii (P2) } & Leaves & $21.03 a$ & $1.16 a$ & $6.14 a b$ & $6.16 c$ & $2.39 a$ & $1.23 b$ \\
\hline & Branches & $3.02 \mathrm{a}$ & $0.22 \mathrm{a}$ & $2.48 a b$ & $4.98 \mathrm{~b}$ & $0.85 b c$ & $0.24 a b$ \\
\hline & Stembark & $4.10 a$ & $0.50 a$ & $3.82 b c$ & $10.40 b$ & 3.31a & $0.39 a b$ \\
\hline & Stemwood & $1.51 \mathrm{ab}$ & $0.16 a$ & 1.77ab & $0.51 c$ & $0.22 b c$ & $0.14 b c$ \\
\hline \multirow{4}{*}{ E. saligna } & Leaves & $15.85 a b$ & $0.80 \mathrm{bc}$ & $6.35 a b$ & $10.96 a b$ & $3.11 a$ & $0.88 c$ \\
\hline & Branches & $1.63 b$ & $0.09 a$ & $1.83 b$ & $10.61 a$ & $2.00 a$ & $0.22 \mathrm{ab}$ \\
\hline & Stembark & $4.61 a$ & $0.25 b$ & $2.50 \mathrm{~d}$ & $11.01 \mathrm{ab}$ & $3.67 a$ & $0.29 a b$ \\
\hline & Stemwood & $1.17 \mathrm{~b}$ & $0.08 a$ & $1.35 b$ & $0.84 b c$ & $0.50 \mathrm{bc}$ & $0.12 c$ \\
\hline \multirow{4}{*}{ E. dunnii } & Leaves & 17.52ab & $0.92 \mathrm{abc}$ & $5.68 a b$ & 10.69abc & $3.24 a$ & $1.06 \mathrm{bc}$ \\
\hline & Branches & $2.33 a b$ & $0.18 a$ & $3.48 a$ & $8.76 a b$ & $1.76 a b$ & $0.26 \mathrm{ab}$ \\
\hline & Stembark & $2.64 a$ & $0.40 \mathrm{ab}$ & $6.47 a$ & $9.38 \mathrm{~b}$ & $2.91 a$ & $0.25 b$ \\
\hline & Stemwood & $1.44 a b$ & $0.15 a$ & $2.22 a$ & $1.50 a$ & $0.96 a$ & $0.19 a b$ \\
\hline \multirow{4}{*}{ E. uroglobulus } & Leaves & $12.83 b$ & $0.73 c$ & $4.69 b$ & $8.04 b c$ & $1.40 \mathrm{~b}$ & $0.81 \mathrm{c}$ \\
\hline & Branches & $1.59 b$ & $0.13 a$ & $2.44 a b$ & $6.50 \mathrm{ab}$ & $0.59 c$ & $0.24 a b$ \\
\hline & Stembark & $3.38 a$ & $0.44 a b$ & $4.80 \mathrm{~b}$ & $8.96 b$ & $2.77 a$ & $0.29 a b$ \\
\hline & Stemwood & $1.30 \mathrm{ab}$ & $0.10 a$ & $1.81 \mathrm{ab}$ & $0.56 c$ & $0.20 \mathrm{c}$ & $0.18 a b$ \\
\hline \multirow{4}{*}{ E. urograndis } & Leaves & $15.82 a b$ & $0.89 a b c$ & $6.53 a$ & $12.93 a$ & $2.39 a$ & $0.86 c$ \\
\hline & Branches & $1.56 b$ & $0.16 a$ & $2.15 a b$ & $10.71 a$ & $1.88 a b$ & $0.22 b$ \\
\hline & Stembark & $3.25 a$ & $0.37 a b$ & $3.64 c$ & 12.09ab & $3.54 a$ & $0.24 b$ \\
\hline & Stemwood & $1.45 \mathrm{ab}$ & $0.14 a$ & $2.07 a$ & $0.82 \mathrm{bc}$ & $0.52 b$ & $0.18 \mathrm{ab}$ \\
\hline
\end{tabular}

Averages of each fraction of biomass in different treatments (genotypes) followed by equal letters, do not differ significantly by the Tukey test at the $5 \%$ level of error.

concentrated in the leaves. It has also been observed that the highest concentrations of $\mathrm{Ca}$ and $\mathrm{Mg}$ are present in the bark of 9-year-old E. grandis (Freitas et al., 2004), and 10-year-old E. urophylla $\times$ E globulus (Viera et al., 2013) as well as with E. nitens (González-Garcia et al., 2015). According to Freitas et al. (2004), Ca is more concentrated in the bark compared to the other components of the biomass because of its low mobility in the phloem since it is a less redistributed element in plant tissue.

The highest concentrations of micronutrients occurred in the leaves (Table 4), with the exception of clones E. benthamii (P2), E. saligna and E. urograndis, where the concentration of $\mathrm{Mn}$ was higher in the stembark. In general, the macronutrients tended to be distributed in the tree components in the following order: leaves $>$ stembark $>$ branches $>$ stemwood. Similar patterns of distribution were found in 10-year-old $E$. urograndis in Eldorado do Sul, RS, Brazil (Viera et al., 2012); and for the elements N, P, and $\mathrm{K}$ in 2- and 5-year-old $E$. nitens in Spain (Gonzales-Garcia et al., 2015). The micronutrients were also distributed in the same order, except for clones $E$. saligna, $E$. dunnii, and E. urograndis, where higher concentrations of nutrients occurred in the branches than in the stembark. This may be due to the inherent species-to-species variation in nutrient requirement of the trees (Freitas et al., 2004).

There was great variation in the allocation of macro- and micronutrients in the different Eucalyptus species, and in the different components of the same species (Tables 5 and 6). Among the macronutrients, the greatest amount of $\mathrm{N}$ was found in the leaves, ranging from 47 to $55 \%$ for E. dunnii and
E. urograndis, respectively. Similarly, the highest amount of $\mathrm{P}$ was found in the leaves, with the exception of $E$. benthamii (P2) and E. dunnii, in which the largest content of $P$ was found in the stemwood. In general, the highest amounts of $K$ and $S$ were also observed in the stemwood, ranging from $38 \%$ to $53 \%$ for $E$. dunnii and E. benthamii (P2) for $\mathrm{K}$ and from $31 \%$ to $43 \%$ for E. benthamii (P1) and E. uroglobulus for S.

With the exception of $E$. benthamii $(\mathrm{P} 2)(\mathrm{N}>\mathrm{Ca}>\mathrm{K}>\mathrm{Mg}>$ $\mathrm{P}>\mathrm{S}$ ) and $E$. dunnii $(\mathrm{Ca}>\mathrm{K}>\mathrm{N}>\mathrm{Mg}>\mathrm{S}>\mathrm{P})$, the total quantity of macronutrients had the following order of distribution: $\mathrm{Ca}$ $>\mathrm{N}>\mathrm{K}>\mathrm{Mg}>\mathrm{S}>\mathrm{P}$. This order was similar to what has been reported for 9-year-old E. grandis in Alegrete, RS, Brazil (Freitas et al., 2004), 4-year-old E. dunnii also in Alegrete (Guimarães et al., 2015), and E. saligna between 2 and 7 years of age in the Region of Guaíba, RS, Brazil (Witschoreck \& Schumacher, 2015). Viera et al. (2012), studied 18-month-old E. urograndis of in Piratini, RS, Brazil and observed the same sequence, except for an inversion of the values of $S$ and $P$.

In terms of micronutrients, the highest amount of $\mathrm{Zn}$ was found in the stemwood at levels ranging from $38 \%$ to $62 \%$ (E. dunnii and $E$. benthamii (P2)). With the exception of $E$. benthamii ( $\mathrm{P} 1)$ and $E$. dunnii for $\mathrm{Cu}$ (branches), and $E$. dunnii and $E$. urograndis for $\mathrm{Fe}$ (branches), the largest quantities of $\mathrm{Fe}$ and $\mathrm{Cu}$ were also observed in the stemwood at levels ranging from $23 \%$ to $50 \%$ (E. benthamii (P1) and E. uroglobulus) for Fe, and from $21 \%$ to $49 \%$ (E. dunnii and E. saligna) for Cu.

Therefore, with the exception of $E$. benthamii (P2), in which the amount of $\mathrm{Zn}$ was higher than that of $\mathrm{B}$, the order of total distribution for the other micronutrients in Eucalyptus 
Table 4. Microutrient concentration in the different biomass components of different genotypes of Eucalyptus at 43-month-old established in São Gabriel, RS, Brazil.

\begin{tabular}{|c|c|c|c|c|c|c|}
\hline \multirow{2}{*}{ Genotype } & \multirow{2}{*}{ Fractions } & B & $\mathrm{Cu}$ & $\mathrm{Fe}$ & $\mathrm{Mn}$ & $\mathrm{Zn}$ \\
\hline & & \multicolumn{5}{|c|}{$\left(\mathrm{mg} \mathrm{kg}^{-1}\right)$} \\
\hline \multirow{4}{*}{ E. benthamii (P1) } & Leaves & $38.21 a$ & $5.74 \mathrm{bcd}$ & $132.40 \mathrm{ab}$ & $1.187 .01 \mathrm{a}$ & $11.96 a b$ \\
\hline & Branches & $10.19 b$ & $3.72 \mathrm{a}$ & $62.62 a$ & $759.29 a$ & $8.80 a$ \\
\hline & Stembark & $15.67 a$ & $2.55 a b$ & $45.35 a$ & $1.116 .22 \mathrm{a}$ & $11.08 \mathrm{a}$ \\
\hline & Stemwood & $5.57 a$ & $0.80 a$ & $28.00 \mathrm{a}$ & $176.38 a$ & 5.77ab \\
\hline \multirow{4}{*}{ E. benthamii (P2) } & Leaves & $26.40 \mathrm{~b}$ & 7.12abc & $105.83 \mathrm{bc}$ & $974.88 a b$ & $12.80 \mathrm{a}$ \\
\hline & Branches & 11.44ab & $4.28 \mathrm{a}$ & $32.09 a$ & 629.74a & $8.01 a$ \\
\hline & Stembark & $20.53 a$ & $3.54 a$ & $26.69 a$ & $1.080 .40 a b$ & $12.77 a$ \\
\hline & Stemwood & $3.81 a b$ & $1.96 a$ & $16.52 \mathrm{a}$ & $112.33 a$ & $7.18 a$ \\
\hline \multirow{4}{*}{ E. saligna } & Leaves & $30.08 b$ & $5.44 \mathrm{~cd}$ & $96.77 b c$ & $795.97 b$ & 10.59ab \\
\hline & Branches & $11.66 a b$ & $4.83 a$ & $80.73 a$ & $672.05 a$ & $10.42 a$ \\
\hline & Stembark & $15.70 a$ & $2.30 a b$ & $35.89 a$ & $971.83 a b$ & $5.71 a$ \\
\hline & Stemwood & $5.49 a$ & $1.60 a$ & $39.51 a$ & $75.12 \mathrm{a}$ & $6.99 a$ \\
\hline \multirow{4}{*}{ E. dunnii } & Leaves & $26.55 b$ & $8.24 a$ & $159.42 a$ & $986.48 a b$ & $9.48 a b$ \\
\hline & Branches & $14.23 a$ & $4.71 \mathrm{a}$ & $65.06 a$ & $712.64 a$ & $8.07 a$ \\
\hline & Stembark & $18.64 a$ & $1.38 \mathrm{~b}$ & 51.98a & $883.25 b$ & 7.14a \\
\hline & Stemwood & $5.92 a$ & $2.08 a$ & $17.16 a$ & $153.90 a$ & $3.98 a b$ \\
\hline \multirow{4}{*}{ E. uroglobulus } & Leaves & $24.02 b$ & $4.42 d$ & $60.12 c$ & 952.22ab & $8.09 b$ \\
\hline & Branches & 11.15ab & $3.48 a$ & $37.46 a$ & 570.40a & $4.59 a$ \\
\hline & Stembark & $18.73 a$ & $2.42 \mathrm{ab}$ & $48.16 a$ & 923.76ab & $6.31 a$ \\
\hline & Stemwood & $3.05 b$ & $1.85 \mathrm{a}$ & $18.26 a$ & $92.98 a$ & $3.12 b$ \\
\hline \multirow{4}{*}{ E. urograndis } & Leaves & $42.88 a$ & 7.15ab & 113.31ab & $881.03 a b$ & 12.12ab \\
\hline & Branches & 11.29ab & $4.94 a$ & $84.99 a$ & $751.30 a$ & $8.33 a$ \\
\hline & Stembark & $14.67 a$ & $2.31 a b$ & $36.67 a$ & $978.55 a b$ & $7.74 a$ \\
\hline & Stemwood & $5.24 a$ & $2.39 a$ & $21.75 a$ & $114.68 a$ & 5.43ab \\
\hline
\end{tabular}

Averages of each fraction of biomass in different treatments (genotypes) followed by equal letters, do not differ significantly by the Tukey test at the $5 \%$ level of error.

Table 5. Amount of macronutrients in the biomass components of different genotypes of Eucalyptus at 43-month-old established in São Gabriel, RS, Brazil.

\begin{tabular}{|c|c|c|c|c|c|c|c|}
\hline \multirow{2}{*}{ Genotypes } & \multirow{2}{*}{ Fractions } & $\mathbf{N}$ & $\mathbf{P}$ & K & $\mathrm{Ca}$ & $\mathrm{Mg}$ & $S$ \\
\hline & & \multicolumn{6}{|c|}{$\left(\mathrm{kg} \mathrm{ha}^{-1}\right)$} \\
\hline \multirow{4}{*}{ E. benthamii (P1) } & Leaves & 110.29 & 6.36 & 36.30 & 69.09 & 16.89 & 9.51 \\
\hline & Branches & 20.17 & 1.39 & 19.27 & 103.17 & 17.40 & 2.89 \\
\hline & Stemwood & 52.27 & 5.08 & 64.61 & 38.78 & 16.14 & 6.60 \\
\hline & Total & 206.72 & 15.26 & 144.89 & 294.89 & 68.94 & 21.55 \\
\hline \multirow[t]{3}{*}{ E. benthamii (P2) } & Stembark & 18.01 & 2.18 & 16.62 & 46.40 & 14.50 & 1.68 \\
\hline & Stemwood & 50.34 & 5.34 & 60.06 & 17.06 & 7.48 & 4.68 \\
\hline & Total & 165.64 & 13.18 & 114.27 & 115.53 & 36.01 & 12.39 \\
\hline \multirow[b]{3}{*}{ E. saligna } & Leaves & 92.87 & 4.66 & 37.16 & 63.83 & 18.18 & 5.11 \\
\hline & Branches & 20.71 & 1.13 & 23.35 & 133.81 & 25.39 & 2.80 \\
\hline & Stembark & 28.28 & 1.53 & 15.48 & 68.17 & 22.67 & 1.79 \\
\hline \multirow{4}{*}{ E. dunnii } & Branches & 19.40 & 1.43 & 28.60 & 72.05 & 14.85 & 2.17 \\
\hline & Stembark & 9.82 & 1.49 & 24.32 & 34.85 & 10.88 & 0.93 \\
\hline & Stemwood & 26.92 & 2.72 & 41.61 & 28.23 & 17.87 & 3.61 \\
\hline & Total & 105.71 & 8.24 & 110.58 & 165.55 & 52.90 & 9.71 \\
\hline \multirow{5}{*}{ E. uroglobulus } & Leaves & 133.34 & 7.59 & 48.76 & 83.30 & 14.54 & 8.46 \\
\hline & Branches & 18.19 & 1.52 & 27.98 & 74.96 & 6.75 & 2.75 \\
\hline & Stembark & 22.61 & 2.96 & 32.25 & 60.29 & 18.63 & 1.95 \\
\hline & Stemwood & 71.89 & 5.32 & 100.21 & 30.90 & 11.24 & 9.94 \\
\hline & Total & 246.03 & 17.39 & 209.21 & 249.46 & 51.15 & 23.09 \\
\hline
\end{tabular}

Continues on the next page 
Continued from Table 5

\begin{tabular}{|c|c|c|c|c|c|c|c|}
\hline \multirow{2}{*}{ Genotypes } & \multirow{2}{*}{ Fractions } & $\mathbf{N}$ & $\mathbf{P}$ & $\mathbf{K}$ & $\mathrm{Ca}$ & $\mathrm{Mg}$ & $\mathbf{S}$ \\
\hline & & \multicolumn{6}{|c|}{$\left(\mathrm{kg} \mathrm{ha}^{-1}\right)$} \\
\hline \multirow{5}{*}{ E. urograndis } & Leaves & 142.99 & 8.03 & 59.01 & 117.18 & 21.60 & 7.76 \\
\hline & Branches & 32.43 & 3.38 & 44.77 & 222.54 & 38.96 & 4.52 \\
\hline & Stembark & 21.70 & 2.49 & 24.23 & 80.53 & 23.61 & 1.61 \\
\hline & Stemwood & 64.32 & 6.40 & 91.76 & 36.14 & 22.92 & 8.04 \\
\hline & Total & 261.43 & 20.30 & 219.77 & 456.39 & 107.09 & 21.93 \\
\hline
\end{tabular}

Table 6. Amount of micronutrients in the biomass components of different genotypes of Eucalyptus at 43-month-old established in São Gabriel, RS, Brazil.

\begin{tabular}{|c|c|c|c|c|c|c|}
\hline \multirow{2}{*}{ Genotypes } & \multirow{2}{*}{ Fractions } & B & $\mathrm{Cu}$ & $\mathrm{Fe}$ & $M n$ & $\mathrm{Zn}$ \\
\hline & & \multicolumn{5}{|c|}{$\left(\mathrm{g} \mathrm{ha}^{-1}\right)$} \\
\hline \multirow{4}{*}{ E. benthamii (P1) } & Leaves & 232.91 & 34.96 & 807.86 & 7246.14 & 72.86 \\
\hline & Branches & 103.52 & 37.84 & 633.15 & 7724.68 & 89.40 \\
\hline & Stemwood & 185.40 & 26.61 & 938.24 & 5893.36 & 191.70 \\
\hline & Total & 614.84 & 114.52 & 2648.83 & 27483.72 & 419.74 \\
\hline \multirow[t]{3}{*}{ E. benthamii (P2) } & Stembark & 92.13 & 15.54 & 117.35 & 4793.05 & 52.87 \\
\hline & Stemwood & 128.72 & 66.64 & 552.20 & 3707.66 & 242.54 \\
\hline & Total & 389.75 & 134.92 & 1255.47 & 15971.56 & 390.40 \\
\hline \multirow[b]{3}{*}{ E. saligna } & Leaves & 175.35 & 31.89 & 567.13 & 4657.27 & 62.03 \\
\hline & Branches & 148.13 & 61.46 & 1032.35 & 8514.80 & 132.11 \\
\hline & Stembark & 98.11 & 14.18 & 225.10 & 6032.84 & 35.32 \\
\hline \multirow{4}{*}{ E. dunnii } & Branches & 117.45 & 39.06 & 543.18 & 5873.21 & 66.11 \\
\hline & Stembark & 69.71 & 5.17 & 194.45 & 3308.41 & 26.86 \\
\hline & Stemwood & 111.26 & 38.79 & 323.09 & 2884.73 & 74.93 \\
\hline & Total & 373.91 & 106.39 & 1517.86 & 14868.75 & 194.77 \\
\hline \multirow{5}{*}{ E. uroglobulus } & Leaves & 250.35 & 45.93 & 623.97 & 9884.07 & 84.10 \\
\hline & Branches & 127.94 & 40.39 & 430.87 & 6556.34 & 52.94 \\
\hline & Stembark & 125.44 & 16.35 & 325.35 & 6195.22 & 42.41 \\
\hline & Stemwood & 168.88 & 102.30 & 1013.28 & 5126.07 & 171.83 \\
\hline & Total & 672.61 & 204.97 & 2393.47 & 27761.70 & 351.28 \\
\hline \multirow[b]{3}{*}{ E. urograndis } & Leaves & 387.63 & 64.75 & 1026.00 & 7967.63 & 109.80 \\
\hline & Branches & 234.21 & 102.64 & 1777.39 & 15634.53 & 173.32 \\
\hline & Stembark & 97.86 & 15.35 & 244.60 & 6526.83 & 51.82 \\
\hline
\end{tabular}

species was: $\mathrm{Mn}>\mathrm{Fe}>\mathrm{B}>\mathrm{Zn}>\mathrm{Cu}$. This trend was similar to that reported by Viera et al. (2012) for E. urograndis and by Guimarães et al. (2015) for E. dunnii.

The $E$. urograndis hybrid showed the highest total amounts of macro- and micronutrients, with the exception of $S$ that was present in greater quantity in $E$. uroglobulus. Compared to the clones E. dunnii, E. benthamii (P2), and $E$. saligna, E. urograndis showed $60 \%, 37 \%$, and $26 \%$ higher $\mathrm{N}$; $59 \%, 35 \%$, and $46 \%$ higher $\mathrm{P}$; and $50 \%, 48 \%$, and $39 \%$ higher $\mathrm{K}$, respectively.

The distribution of nutrients generally differs from the observed biomass standard because of the difference in nutrient concentrations between the components of the trees (Reis \& Barros, 1990). In this context, tree canopy biomass (leaves and branches) ranged from $21 \%$ to $37 \%$ (E. benthamii (P2) and E. urograndis) of the total biomass and accumulated
$47 \%$ to $65 \%$ of total macronutrients and $46 \%$ to $67 \%$ of total micronutrients ( $E$. benthamii (P2) and E. urograndis), while wood biomass (wood and bark) ranged from $63 \%$ to $79 \%$ ( $E$. urograndis and $E$. benthamii (P2)) and accumulated $35 \%$ to $53 \%$ of total macronutrients and $33 \%$ to $54 \%$ (E. urograndis and $E$. benthamii (P2)) of total micronutrients. In young stands, according to Reis \& Barros (1990), the contribution of the canopy is high and since the concentration of nutrients is higher in the leaves, the canopy contains more than $50 \%$ of the nutrients of the plant.

\section{Exportation of nutrients by biomass harvest}

Tables 7 and 8 shows the macro and micronutrients export estimates for the three proposed harvest scenarios. Harvesting only the stemwood showed the lowest nutrient removal from the system, regardless of the genotypes. This scenario 
Table 7. Macronutrient export estimates for the three proposed harvest scenarios.

\begin{tabular}{|c|c|c|c|c|c|c|c|}
\hline \multirow{2}{*}{ Genotypes } & \multirow{2}{*}{ Intensity } & $\mathbf{N}$ & $\mathbf{P}$ & $K$ & $\mathrm{Ca}$ & $\mathrm{Mg}$ & $S$ \\
\hline & & \multicolumn{6}{|c|}{$\left(\right.$ kg ha $\left.^{-1}\right)$} \\
\hline \multirow[b]{2}{*}{ E. benthamii (P1) } & $1^{*}$ & 52.27 & 5.08 & 64.61 & 38.78 & 16.14 & 6.60 \\
\hline & 2 & 76.25 & 7.51 & 89.33 & 122.63 & 34.65 & 9.15 \\
\hline \multirow[b]{2}{*}{ E. benthamii (P2) } & 1 & 50.34 & 5.34 & 60.06 & 17.06 & 7.48 & 4.68 \\
\hline & 2 & 68.34 & 7.52 & 76.69 & 63.45 & 21.98 & 6.37 \\
\hline \multirow[t]{2}{*}{ E. saligna } & 2 & 79.57 & 5.16 & 74.53 & 104.94 & 44.36 & 7.10 \\
\hline & 3 & 193.15 & 10.96 & 135.04 & 302.58 & 87.94 & 15.01 \\
\hline \multirow{3}{*}{ E. dunnii } & 1 & 26.92 & 2.72 & 41.61 & 28.23 & 17.87 & 3.61 \\
\hline & 2 & 36.73 & 4.21 & 65.93 & 63.08 & 28.75 & 4.54 \\
\hline & 3 & 105.71 & 8.24 & 110.58 & 165.55 & 52.90 & 9.71 \\
\hline E. uroglobulus & 1 & 71.89 & 5.32 & 100.21 & 30.90 & 11.24 & 9.94 \\
\hline \multirow[t]{2}{*}{ E. urograndis } & 2 & 86.01 & 8.89 & 115.99 & 116.66 & 46.53 & 9.66 \\
\hline & 3 & 261.43 & 20.30 & 219.77 & 456.39 & 107.09 & 21.93 \\
\hline
\end{tabular}

$1^{*}$ - Harvesting the stemwood; 2 - Harvesting the stemwood with stembark; 3 - Harvesting of all aboveground biomass.

Table 8. Micronutrient export estimates for the three proposed harvest scenarios.

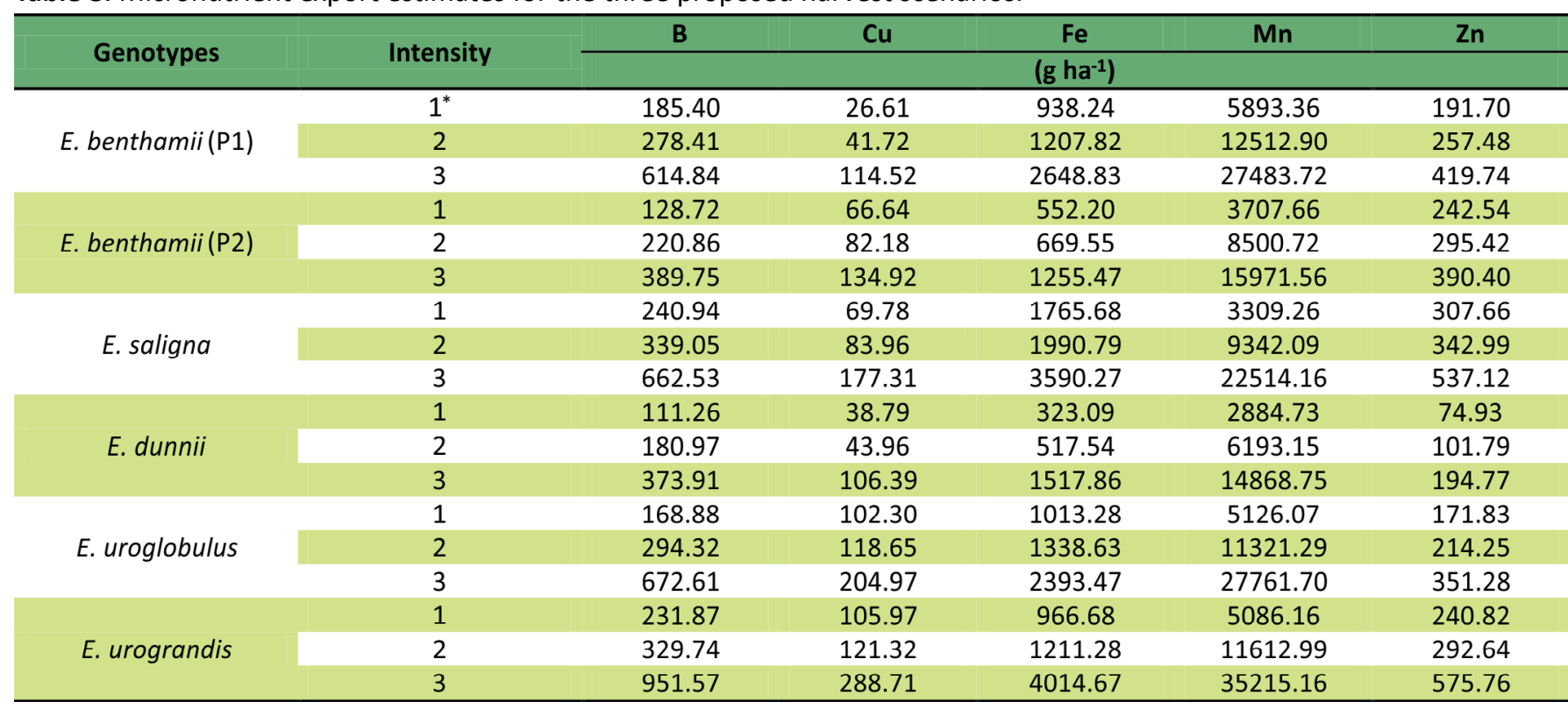

$1^{*}$ - Harvesting the stemwood; 2 - Harvesting the stemwood with stembark; 3 - Harvesting of all aboveground biomass.

maintained the macro and micronutrients accumulated in the other biomass components, which varied from $70 \%$ to $75 \%$ of $\mathrm{N}$ (E. benthamii (P2) and E. urograndis); $59 \%$ to $69 \%$ of $\mathrm{P}$ (E. benthamii (P2) and E. uroglobulus); $47 \%$ to $62 \%$ of $\mathrm{K}$ ( $E$. benthamii (P2) and E. dunnii); $83 \%$ to $92 \%$ Ca (E. dunnii and E. urograndis); $66 \%$ to $79 \%$ of $\mathrm{Mg}$ (E. dunnii and E. benthamii (P2)); $57 \%$ to $69 \%$ of $S$ (E. uroglobulus and E. benthamii (P1)); $64 \%$ to $76 \%$ of $\mathrm{B}$ (E. saligna and $E$. urograndis); $50 \%$ to $77 \% \mathrm{Cu}$ (E. uroglobulus and E. benthamii (P1)); $51 \%$ to $79 \%$ of Fe (E. saligna and E. dunnii); $77 \%$ to $86 \%$ of $\mathrm{Mn}$ (E. benthamii (P2) and E. urograndis); and $38 \%$ to $62 \%$ of $\mathrm{Zn}$ (E. benthamii (P2) and $E$. dunnii). On the other hand, harvesting the stemwood and the stembark resulted in the reduction in nutrient levels in the other biomass components by the following amounts: from $59 \%$ to $67 \%$ of $\mathrm{N}$; from $43 \%$ to $56 \%$ of $\mathrm{P}$; from $33 \%$ to $47 \%$ of $\mathrm{K}$; from $45 \%$ to $74 \% \mathrm{Ca}$; from $39 \%$ to $57 \%$ of $\mathrm{Mg}(E$. benthamii (P2) and E. uroglobulus); and from $49 \%$ to $58 \%$ of $S$ (E. uroglobulus and E. benthamii (P1)); from $43 \%$ to $65 \%$ of B (E. benthamii (P2) and E. urograndis); from $39 \%$ to $64 \%$ of $\mathrm{Cu}($ E. benthamii $(\mathrm{P} 2)$ and E. benthamii (P1); from $44 \%$ to $70 \%$ of Fe (E. uroglobulus and E. urograndis); from $47 \%$ to $67 \%$ of $\mathrm{Mn}$, and from $24 \%$ to $49 \%$ of $\mathrm{Zn}$ (E. benthamii (P2) and $E$. urograndis).

In the case of macronutrients, it was observed that, in the first scenario (harvesting of stemwood), in all the genotypes, the element removed in the greatest quantity was $\mathrm{K}$. In the second scenario (harvesting of stemwood with bark) the highest removal occurred with Ca (E. benthamii (P1), E. saligna 
and $E$. urograndis), and with $\mathrm{K}$ (E. benthamii (P2), E. dunnii and $E$. uroglobulus). In the third scenario (harvesting of all biomass aboveground), the macronutrient removed in the greatest quantity was $\mathrm{Ca}$, except in E. benthamii (P2), where the largest export occurred with $\mathrm{N}$. Therefore, when removing the trunk, debarking of the trees in the stands should be carried out to reduce the export of Ca. In this way, soils with lower concentrations of this nutrient could have their productivity preserved for a longer period. In the case of the micronutrients, in all the studied scenarios, the elements removed in greatest and least quantities were $\mathrm{Mn}$ and $\mathrm{Cu}$, respectively.

The highest amount of nutrients exported with the biomass harvest for the first and second scenarios occurred in E. uroglobulus ( $\mathrm{N}, \mathrm{K}$ and $\mathrm{S})$, E. urograndis $(\mathrm{P}, \mathrm{Mg}$ and $\mathrm{Cu}$ ) and E. saligna ( $\mathrm{B}, \mathrm{Fe}$ and $\mathrm{Zn})$. For the third scenario, the highest amount of export of nutrients occurred in $E$. urograndis, except for $\mathrm{S}$, where the highest removal occurred in $E$. uroglobulus. In contrast, for the first and second scenarios, $E$. dunnii exported the smallest amounts of (scenario 1) N, P, K and $\mathrm{Ca}$; and (scenario 2), S, B, Cu, Fe, Mn, and $\mathrm{Zn}$. Therefore, the knowledge of the export rate of nutrients by different species and provenances is of paramount importance for implementing sustainable forest management techniques. In this context, for sustainable land use, the nutrient loss must be remedied by application of fertilisers, which usually increases the input costs and hence the energy cost from the biomass (Guo et al., 2002).

It should be noted that the age of cut exerts a marked influence on the export of nutrients. The harvest of young stands tends to export more nutrients per unit of biomass, and with the increase in age, there is a greater efficiency in the use of nutrients and consequently less export of these elements (Viera et al., 2015).

\section{Conclusions}

Different genotypes produced different levels of biomass, and the hybrids $E$. uroglobulus and $E$. urograndis showed superior biomass production levels compared to the other clones. In contrast, E. dunnii showed the lowest production.

There was great variation in the concentration and allocation of the amount of nutrients in the different Eucalyptus species, and in the different components of the same genotypes.

E. urograndis presented the highest total amounts of macro and micronutrients, with the exception of $S$ that was present in greater quantity in $E$. uroglobulus.

Harvesting only the stemwood showed the lowest nutrient removal from the system, regardless of the genotypes.

\section{Literature Cited}

Alvares, C.A.; Stape, J.L.; Sentelhas, P.C.; Gonçalves, J.L.M.; Sparovek, G. Köppen's climate classification map for Brazil. Meteorologische Zeitschrift, v.22, n.6, p.711-728, 2013. http:// dx.doi.org/10.1127/0941-2948/2013/0507.
Bellote, A.F.J.; Silva, H.D. Sampling techniques and nutritional evaluations in eucalypt plantations, In: Gonçalves; J.L.M.; Benedetti V. (Eds.). Forest nutrition and fertilization. Piracicaba: IPEF, 2004. p. 113-139.

Empresa Brasileira de Pesquisa Agropecuária - Embrapa. Centro Nacional de Pesquisa de Solos. Sistema brasileiro de classificação de solos. Rio de Janeiro: Embrapa, 2009. 412p.

Freitas, R.; Schumacher, M.V.; Caldeira, M.V.W; Spathelf, P. Biomassa e conteúdo de nutrientes em povoamento de Eucalyptus grandis W. Hill ex Maiden plantado em solo sujeito à arenização, no município de Alegrete-RS. Renabio, v.1, n.1, p.93-104, 2004.

Gonçalves, J.L.M.; Alvares, C.A.; Higa, A.R.; Silva, L.D.; Alfenas, A.C.; Stahl, J.; Ferraz, S.B.; Lima, W.P.; Brancalion, P.H.S.; Hubner, A.; Bouillet, J.P.D.; Laclau, J.P.; Nouvellon, Y.; Epron, D. Integrating genetic and silvicultural strategies to minimize abiotic and biotic constraints in Brazilian eucalypt plantations. Forest Ecology and Management, v.301, p.6-27, 2013. https://doi.org/10.1016/j. foreco.2012.12.030.

González-García, M.; Hevea, A.; Majada, J.; Rubiera, F.; Barrio-Anta, F. Nutritional, carbon and energy evaluation of Eucalyptus nitens short rotation bioenergy plantations in northwestern Spain. iForest, v.9, p.303-310, 2015. https://doi.org/10.3832/ifor1505-008.

Guimarães, C.C.; Schumacher, M.V.; Witschoreck, R.; Souza H.P.; Santos, J.C. Biomassa e nutrientes em povoamento de Eucalyptus dunnii Maiden no Pampa Gaúcho. Revista Árvore, v.39, n.5, p.873882, 2015. https://doi.org/10.1590/0100-67622015000500010.

Guo, L.B.; Sims, R.E.H.; Horne, D.J. Biomass production and nutrient cycling in Eucalyptus short rotation energy forests in New Zealand.: I: biomass and nutrient accumulation. Bioresource Technology, v.85, n.3, p.273-283, 2002. https://doi.org/10.1016/ s0960-8524(02)00118-9.

Instituto Brasileira de Geografia e Estatística - IBGE. Produção da extração vegetal e da silvicultura. Rio de Janeiro: IBGE, 2017. v.32, p.1-8.

Kuyah, S.; Dietz, J.; Muthuri, C.; Noordwijk, M.; Neufeldt, H. Allometry and partitioning of above- and bellow-ground biomass in farmed eucalyptus species dominant in Western Kenyan agricultural landscapes. Biomass and Bioenergy, v.55, n.1, p.276-284, 2013. https://doi.org/10.1016/j.biombioe.2013.02.011.

Miyazawa, M.; Pavan, M.A.; Muraoka, T. Análises químicas de tecido vegetal. In: Silva, F.C. (Org.). Manual de análises químicas de solos, plantas e fertilizantes. Brasília: Embrapa Comunicação para Transferência de Tecnologia, 1999. p. 171-224.

Reis, M.G.F.; Barros, N.F. Ciclagem de nutrientes em plantios de eucalipto. In: Barros, N.F.; Novais, R.F. (Eds.). Relação soloeucalipto. Viçosa: Folha de Viçosa, 1990. p. 265-302.

Ribeiro, S.C.; Soares, C.P.B.; Fehrmann, L.; Jacovine, L.A.G.; Gadow, K.; Soares, C.P.B.; Fehrmann, L.; Jacovine, L.A.G.; Gadow, K. Aboveground and belowground biomass and carbon estimates for clonal Eucalyptus trees in southeast Brazil. Revista Árvore, v.39, n.2, p.353-363, 2015. https://doi.org/10.1590/010067622015000200015.

Santana, R.C.; Barros, N.F.; Novais, R.F.; Leite, H.G.; Comerford, N.B. Alocação de nutrientes em plantios de eucalipto no Brasil. Revista Brasileira de Ciência do Solo, v.32, n.spe, p. p.2723-2733, 2008. https://doi.org/10.1590/S0100-06832008000700016. 
Santana, R.C.; Barros, N.F.; Neves, J.C.L. Biomassa e conteúdo de nutrientes de procedências de Eucalyptus grandis e Eucalyptus saligna em alguns sítios florestais do Estado de São Paulo. Scientia Forestalis, n.56, p.155-169, 1999. http://www.ipef.br/ publicacoes/scientia/nr56/cap12.pdf. 30 Nov. 2017.

Santana, R.C.; Barros, N.F.; Neves, J.C.L. Eficiência de utilização de nutrientes e sustentabilidade da produção em procedências de Eucalyptus grandis e Eucalyptus saligna em sítios florestais do estado de São Paulo. Revista Árvore, v.26, n.4, p.447-457, 2002. https://doi.org/10.1590/S0100-67622002000400007.

Schumacher, M.V.; Witschoreck, R.; Calil, F.N.; Lopes, V.G. Biomassa e nutrientes no corte raso de um povoamento de Pinus taeda L. de 27 anos de idade em Cambará do Sul - RS. Ciência Florestal, v.23, n.2, p.321-332, 2013. https://doi. org/10.5902/198050989278.

Schumacher, M.V.; Caldeira, M.V.W. Quantificação de biomassa em povoamentos de Eucalyptus saligna Sm. com diferentes idades. Renabio, v.32, p.2723-2733, 2008.

Schumacher, M.V.; Witschorek, R.; Calil, F.N.; Lopes, V.G. Biomassa e nutrientes no corte raso de um povoamento de Pinus taeda $\mathrm{L}$. de 27 anos de idade em Cambará do Sul - RS. Ciência Florestal, v.21, n.1, p.17-22, 2011. https://doi.org/10.5902/198050989278.

Silva, F.A.Z.; Azevedo, C.A.V. Principal components analysis in the software assistat statistical attendance. In: Word Congress on Computers in Agriculture, 7., 2009, Reno. Proceedings... Reno: American Society of Agricultural and Biological Engineers, 2009.
Tedesco, M.J.; Gianello, C.; Bissani, C.A.; Bohnen, H.; Volkweiss, S. J. Análise de solo, plantas e outros materiais. Porto Alegre: UFRGS; Departamento de Solo, 1995. 174p.

Turner, J.; Lambert, M.J. Nutrient cycling in age sequences of two Eucalyptus plantation species (2008). Forest Ecology and Management, v.255, n.5-6, p.1701-1712, 2008. https://doi. org/10.1016/j.foreco.2007.11.038.

Viera, M.; Bonacina, D.M.; Schumacher, M.V.; Calil, F.N.; Caldeira, M.V.W.; Watzlawick, L. F. Biomassa e nutrientes em povoamento de Eucalyptus urograndis na Serra do Sudeste-RS. Semina: Ciências Agrárias, v.33, n.6, supl. 11, p.2481-2490, 2012. https:// doi.org/10.5433/1679-0359.2012v33n6Supl1p2481.

Viera, M.; Schumacher, M.V.; Caldeira, M.V.W. Biomassa e exportação de nutrientes pela colheita do eucalipto. In: Schumacher; M.V.; Viera; M. (Eds.). Silvicultura do eucalipto no Brasil. Santa Maria: UFSM, 2015. p. 245-272.

Viera, M.; Schumacher, M.V.; Trüby, P.; Araújo, E.F. Biomassa e nutrientes em um povoamento de Eucalyptus urophylla $\mathrm{x}$ Eucalyptus globulus, em Eldorado do Sul-RS. ENFLO, v.1, n.1, p.113, 2013. https://doi.org/10.13086/2316-980x.v01n01a01.

Witschoreck, R.; Schumacher, M.V. Alocação de nutrientes em povoamenos de Eucalyptus saligna SM. na região de Guaíba - Rio Grande do Sul. Cerne, v.21, n.4, p.625-632, 2015. https://doi.org /10.1590/01047760201521041963.

Zewdie, M.; Olsson, M.; Verwijst, T. Above-ground biomass production and allometric relations of Eucalyptus globulus Labill. Biomass and Bioenergy, v.33, n.3, p.421-428, 2009. https://doi. org/10.1016/j.biombioe.2008.08.007. 